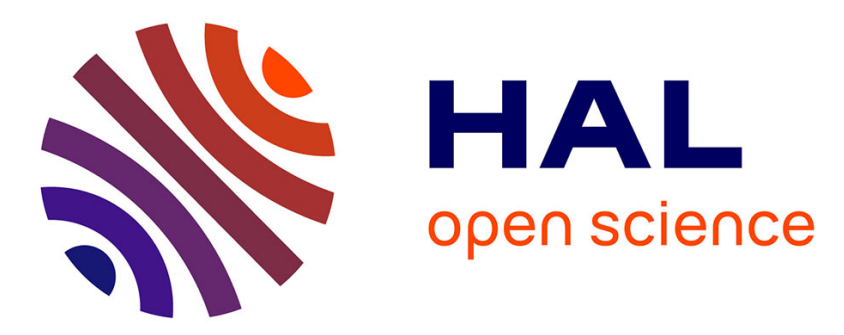

\title{
THE CLINICAL POTENTIAL OF THE ACYCLIC (AND CYCLIC) NUCLEOSIDE PHOSPHONATES. THE MAGIC OF THE PHOSPHONATE BOND
}

Erik de Clercq

\section{> To cite this version:}

Erik de Clercq. THE CLINICAL POTENTIAL OF THE ACYCLIC (AND CYCLIC) NUCLEOSIDE PHOSPHONATES. THE MAGIC OF THE PHOSPHONATE BOND. Biochemical Pharmacology, 2011, 10.1016/j.bcp.2011.03.027 . hal-00703552

HAL Id: hal-00703552

https://hal.science/hal-00703552

Submitted on 3 Jun 2012

HAL is a multi-disciplinary open access archive for the deposit and dissemination of scientific research documents, whether they are published or not. The documents may come from teaching and research institutions in France or abroad, or from public or private research centers.
L'archive ouverte pluridisciplinaire HAL, est destinée au dépôt et à la diffusion de documents scientifiques de niveau recherche, publiés ou non, émanant des établissements d'enseignement et de recherche français ou étrangers, des laboratoires publics ou privés. 


\section{Accepted Manuscript}

Title: THE CLINICAL POTENTIAL OF THE ACYCLIC (AND CYCLIC) NUCLEOSIDE PHOSPHONATES. THE MAGIC OF THE PHOSPHONATE BOND

Author: Erik De Clercq

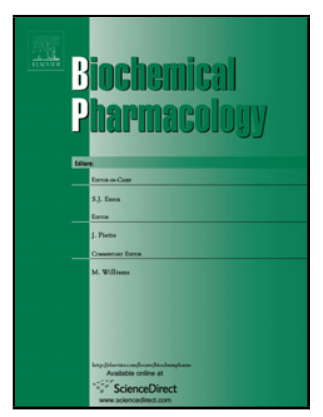

PII:

S0006-2952(11)00214-0

DOI: doi:10.1016/j.bcp.2011.03.027

Reference: BCP 10867

To appear in: $\quad B C P$

Received date: 21-2-2011

Revised date: 28-3-2011

Accepted date: $\quad 31-3-2011$

Please cite this article as: De Clercq E, THE CLINICAL POTENTIAL OF THE ACYCLIC (AND CYCLIC) NUCLEOSIDE PHOSPHONATES. THE MAGIC OF THE PHOSPHONATE BOND, Biochemical Pharmacology (2010), doi:10.1016/j.bcp.2011.03.027

This is a PDF file of an unedited manuscript that has been accepted for publication. As a service to our customers we are providing this early version of the manuscript. The manuscript will undergo copyediting, typesetting, and review of the resulting proof before it is published in its final form. Please note that during the production process errors may be discovered which could affect the content, and all legal disclaimers that apply to the journal pertain. 
Ref.: Ms. No. BCP-D-11-00174

Revised

\section{COMMENTARY}

THE CLINICAL POTENTIAL OF THE ACYCLIC (AND CYCLIC) NUCLEOSIDE PHOSPHONATES. THE MAGIC OF THE PHOSPHONATE BOND

Erik De Clercq

Department of Microbiology and Immunology, K.U.Leuven

Rega Institute for Medical Research

Minderbroedersstraat 10

B-3000 Leuven, Belgium

*Corresponding author. Tel: + 3216337367

E-mail address: erik.declercq@rega.kuleuven.be 


\section{Running title page}

Running title: Acyclic (and cyclic) nucleoside phosphonates.

Keywords: Antiviral; phosphonate; nucleotide. 


\section{ABSTRACT}

The use of the acyclic nucleoside phosphonates, starting with (S)-HPMPA as the prototype, yielded three clinically approved antiviral drugs, cidofovir for the treatment of CMV retinitis in AIDS patients, adefovir dipivoxil for the treatment of chronic hepatitis B and tenofovir disoproxil fumarate for the treatment of HIV infections (AIDS) and HBV infections. This era has now grown to many more acyclic (and cyclic) nucleoside phosphonates (such as the "open ring" DAPy and Fd4A phosphonates) and alkoxyalkyl and phosphonoamidate prodrugs thereof, as well as new clinical applications, including new drug combination regimens for the treatment of AIDS, the chemoprophylaxis of HIV infections, and the anticancer potential against some malignant disorders. 


\section{Introduction}

In 2011 it will be exactly 25 years ago when we published in Nature [1] on "a novel selective broad-spectrum anti-DNA virus agent". The name of the compound, (S)-9-(3hydroxy-2-phosphonylmethoxypropyl)adenine [(S)-HPMPA], was not revealed in the title of the Nature paper. Five years ago, we published on "antiviral treatment is more effective than smallpox vaccination upon lethal monkeypox virus infection", again in Nature [2] without the name of the antiviral compound, (S)-1-(3-hydroxy-2phosphonylmethoxypropyl)cytosine [(S)-HPMPC], being unveiled in the title of the paper.

(S)-HPMPA and (S)-HPMPC [3] heralded the advent of a totally new and unique class of antiviral drugs, the acyclic nucleoside phosphonates (ANPs) [4], which all originated from Antonin Holý's Laboratory at IOCB (Institute of Organic Chemistry and Biochemistry, Prague, Czech Republic), and with tenofovir have yielded one of the most successful drugs in the treatment of HIV, as well as HBV, infections (AIDS).

What is so special about the ANPs ? How were they discovered ? What makes them uniquely different from the other antiviral drugs ? Could the ANPs, and particularly tenofovir, cure the disease (i.e. AIDS) ? Or could it be used prophylactically to prevent HIV infection ? Or are any new, nucleoside phosphonates, whether acyclic or cyclic, forthcoming? How could prodrugs be designed for the nucleoside phosphonates to better reach their target site in the organism ? Addressing these questions will open new perspectives for the clinical usefulness of these nucleotide analogues, thereby pertaining to the importance (or "magic") of the phosphonate bound.

\section{2. (S)-HPMPA: the prototype of the acyclic nucleoside phosphonates}


The first acyclic nucleoside phosphonate that opened the era of nucleotide analogs as potential antiviral drugs was (S)-HPMPA [1]. The compound could be conceived as the hybrid between the broad-spectrum antiviral agent (S)-9-(2,3-dihydroxypropyl)adenine (DHPA) [5] and the specific anti-DNA virus agent phosphonoformic acid (PFA) (Fig. 1). (S)HPMPA exhibited activity against a variety of DNA viruses, including herpesviruses [herpes simplex virus type 1 (HSV-1) and type 2 (HSV-2), varicella-zoster virus (VZV), cytomegalovirus (CMV)], poxviruses (i.e. vaccinia virus) and adenoviruses [1], and, as shown later [6,7], hepadnaviruses (i.e. hepatitis B virus (HBV)] as well.

The anti-poxvirus activity of (S)-HPMPA could be markedly increased both in vitro and in vivo when alkoxyalkyl [i.e. hexadecyloxypropyl (HDP) or octadecyloxyethyl (ODE)] esters were attached to (S)-HPMPA [8,9] (Fig. 1). Similarly, the activity of (S)-HPMPA against CMV [8] and adenovirus [10] could be markedly enhanced when converting (S)-HPMPA into its prodrugs with HDP or ODE (for a current state of the art on the antiviral activity of alkoxyalkyl prodrugs of acyclic nucleoside phosphonates, see [11]).

(S)-HPMPA is virtually inactive against HIV [12], and no antiviral activity has ever been noted with (S)-HPMPA or any other acyclic nucleoside phosphonate(s) against RNA viruses. It is surprising, therefore, that the HDP and ODE esters of (S)-HPMPA would be active (in the 0.4-7 nanomolar range) against HIV-1 [13] and even more surprising that HDPand ODE-(S)-HPMPA should be effective against hepatitis C virus (HCV) replication [ODE-(S)HPMPA at a $50 \%$ effective concentration of about $1 \mu \mathrm{M})$ [14].

\section{3. (S)-HPMPC: the first acyclic nucleoside phosphonate to be licensed for clinical use}

Shortly after (S)-HPMPA, its cytosine counterpart, (S)-HPMPC (cidofovir, Vistide ${ }^{\circledast}$ ) (Fig. 2) was reported as a broad-spectrum anti-DNA viral agent, with an activity spectrum similar to 
that of (S)-HPMPA [3]. The compound was found to be particularly active against CMV [15], and became the first ANP to be approved in 1996 for the treatment of CMV retinitis in AIDS patients. Nowadays, CMV retinitis has virtually disappeared thanks to the successful treatment of AIDS with anti-HIV drugs. This makes that currently cidofovir (Vistide $\left.{ }^{\circledR}\right)$ is primarily used off-label in the treatment of human papilloma virus (HPV) infections [16], poxvirus infections (i.e. molluscum contagiosum), adenovirus infections, and polyoma (JC and BK) virus infections [17].

Numerous, albeit anecdotal, case reports have pointed to the efficacy of local intratumoral injection, topical application or even systemic (intravenous) injection of cidofovir in patients with hypopharyngeal papilloma [18], laryngeal papilloma [19], recurrent respiratory papillomatosis [20], plantar warts [21], molluscum contagiosum [22], and orf (ecthyma contagiosum) [23]. As mentioned in the Introduction, cidofovir has also proven more efficacious than smallpox vaccination in the prophylaxis of monkeypox virus infection in monkeys [2].

To increase the oral bioavailability of cidofovir, alkoxyalkyl [i.e. hexadecyloxypropyl (HDP) and octadecyloxyethyl (ODE)] esters (Fig. 2) of cidofovir have been developed [11,24]. One of these alkoxyalkyl ester derivatives, i.e. HDP-cidofovir (CMX001) is in clinical development for the therapy and/or prophylaxis of orthopoxvirus infections [11]. In principle, the alkoxyalkyl esters of cidofovir may be considered for any indication applicable to cidofovir: herpes (HSV, CMV), papilloma-, pox-, adeno- and polyomavirus infections.

\section{PMEA: an antiretroviral agent finally licensed for the treatment of hepatitis B}

The antiretroviral properties of 9-(2-phosphonylmethoxyethyl)adenine (PMEA) (Fig. 3), which, unlike (S)-HPMPA and (S)-HPMPC, does not contain a chiral carbon center and, 
therefore, does not exist of $(R)$ - and $(S)$-enantiomers, were first mentioned by De Clercq et al. [1]. From a mechanistic viewpoint, all acyclic nucleoside phosphonates (ANPs) need two consecutive intracellular phosphorylations, to their diphosphate form, before they can interact with their target enzyme (DNA polymerase for DNA viruses, reverse transcriptase for retroviruses) as alternate substrates (with respect to dATP, for PMEA diphosphate or (S)HPMPA diphosphate).

At the DNA polymerase (or reverse transcriptase) level, the ANPs act as obligate chain terminators. For CMV DNA polymerase, two consecutive incorporations of cidofovir [(S)-HPMPC] are required for chain termination to occur [25], while for PMEA, one single molecule incorporated by the viral reverse transcriptase suffices to terminate further chain elongation $[26,27]$.

As for all the ANPs, oral bioavailability of PMEA is limited, which explains why it was converted to its oral prodrug, the bis(pivaloyloxymethyl) ester [28,29] (Fig. 3), which was initially pursued as an anti-HIV drug. However, at the dosage (62.5 mg or $125 \mathrm{mg}$ per day) required to inhibit HIV replication adefovir dipivoxil [the bis(pivaloyloxymethyl) ester of PMEA] was considered too nephrotoxic to permit long-term (> 6 months) use. For the treatment of hepatitis $B$, however [30,31], the dosage of $10 \mathrm{mg}$ adefovir dipivoxil per day sufficed to obtain a $4 \log _{10}$, in HBV titer, without any nephrotoxicity, which made the compound, in 2002, licensed for the treatment of hepatitis B.

\section{5. (R)-PMPA and (R)-PMPDAP: potent and selective antiretroviral agents}

In 1991 we reported the anti-HIV activity of 9-(2RS)-3-fluoro-2phosphonylmethoxypropyl derivatives of adenine and 2,6-diaminopurine [32]. Shortly thereafter, in 1993, we showed that this anti-HIV activity resided with the $(R)$-enantiomers 
and extended to (R)-PMPA and (R)-PMPDAP (Fig. 4) [12]. In vitro (R)-PMPDAP was about 10fold more potent than ( $R$ )-PMPA against HIV, and, likewise, $(R)$-PMPDAP was shown to be about 10 -fold more potent than (R)-PMPA against HBV [33]. Yet, $(R)$-PMPA (tenofovir) was developed further as an anti-HIV drug, and later as an anti-HBV drug as well. Its mechanism of action is assumed to be very similar to that of PMEA (adefovir) in that, following intracellular phosphorylation to its diphosphate, tenofovir acts as an (obligate) chain terminator [34] in both the HIV- and HBV-driven reverse transcriptase reaction.

Of crucial importance for the development of $(R)$-PMPA (tenofovir) were the observations of Tsai et al. [35]: they found that in macaques (R)-PMPA could completely prevent simian immunodeficiency virus (SIV) infection, when administered subcutaneously starting 48 hours before, or 4 or 24 hours after intravenous SIV inoculation. These startling observation could now, 15 years later, be considered of key value in both the therapeutic and prophylactic usefulness of tenofovir in the control of HIV infections.

\section{Tenofovir prodrugs: tenofovir disoproxil fumarate (TDF) and the phosphonoamidate}

\section{GS-7340}

To increase the oral bioavailability of tenofovir, in analogy with the bis(pivaloyloxymethyl) esters of PMEA, the bis(isopropyloxycarbonyloxymethyl) ester of $(R)$ PMPA was prepared $[36,37]$ and this prodrug (tenofovir disoproxil) was then formulated as the fumarate salt (Fig. 5) to be licensed for clinical use for the treatment of HIV infection (AIDS) in 2001, and for the treatment of HBV infection (chronic hepatitis B) in 2008.

To enhance the delivery of tenofovir into the lymphoid cells (peripheral blood lymphocytes and lymphatic tissues), the alaninyl phenyl ester phosphonoamidate of tenofovir, GS-7340 (Fig. 5) was constructed, and this prodrug of tenofovir showed 1,000-fold 
enhanced potency against HIV-1 as compared to the parent tenofovir [38] (Fig. 5). It would now seem imperative to determine the clinical value of GS-7340 relative to that of TDF in the therapy and/or prevention of HIV infections.

A third, orally bioavailable, prodrug of tenofovir is represented by CMX-157 (hexadecyloxypropyl-tenofovir) [39], which may have enhanced potency in vitro against NRTI-resistant HIV strains relative to tenofovir [40] and which is in preclinical development for the treatment of HIV infections [11].

\section{Cyclic nucleoside phosphonates: PMDTT, PMDTA, Fd4A phosphonate (GS-9148) and its phosphonoamidate prodrug GS-9131}

In comparison with the acyclic nucleoside phosphonates, relatively few cyclic nucleoside phosphonates with antiviral potential have been reported, representative examples being the deoxythreosyl phosphonate nucleosides PMDTT and PMDTA [41] (Fig. 6); PMDTT and PMDTA have been reported to be selective anti-HIV agents. However, no follow-up studies on these compounds have so far appeared. Too little is presently known about the activity spectrum (HBV in addition to HIV ?), resistance profile, and pharmacological, pharmacokinetic and toxicological behavior of this type of compounds to assess their therapeutic potential.

Another cyclic nucleoside phosphonate, the $2^{\prime}, 3^{\prime}$-dideoxy-2', $3^{\prime}$-didehydroadenosine (d4A) phosphonate, was already reported in 1991 [42]. Since this compound is efficiently utilized by mitochondrial DNA polymerase $\gamma$, it was suspected to be potentially toxic for the mitochondria [43]. To reduce the risk for mitochondrial toxicity, phosphonomethoxy-2'fluoro-2', 3'-dideoxy-2', 3'-didehydroadenosine (GS-9148) was synthesized (Fig. 6) [44], and this compound, while designed to reduce mitochondrial toxicity potential, also showed a 
favorable in vitro resistance profile, retaining activity against a wide range of NRTI resistance mutations including TAMs, K65R, L74V and M184V [44]. GS-9131, the ethylalaninyl phenyl ester phosphonoamidate prodrug of GS-9148, had a 100-fold greater activity in vitro, and allowed for a substantial accumulation and prolonged retention of GS-9148 diphosphate in peripheral lymphocytes in vivo [45]. Lower doses of orally administered GS-9131 are expected to translate into potent clinical antiviral activity, with lower potential for renal toxicity compared to the acyclic nucleoside phosphonates [46]. GS-9131 (Fig. 6), therefore, seems to be an attractive candidate for clinical development for the therapy and/or prophylaxis of HIV infections.

\section{6-[2-(Phosphonomethoxyalkoxyl]-2,4-diaminopyrimidines}

(DAPys): pyrimidine derivatives that act as purines

In 2002 we reported on the antiviral activity of a new class of acyclic nucleoside phosphonates, 6-[2-(phosphonomethoxy)alkoxy]pyrimidines [47-49]. This class of compounds (Fig. 7) could actually be divided in two subclasses: first (i), the (R)-HPMPODAPy derivatives, which akin to (S)-HPMPC, showed activity against herpes-, adeno-, poxand papillomaviruses, and, second (ii), the PMEO-DAPy, 5-X-PMEO-DAPy and (R)-PMPODAPy derivatives which, akin to PMEA and $(R)$-PMPA, showed activity against retroviruses (HIV-1, HIV-2) and hepadnaviruses (HBV) [50]. The activity of (R)-HPMPO-DAPy against poxviruses (i.e. camelpox) has in the mean time been confirmed [51], and the 5-methylPMEO-DAPy derivative has proven to exhibit pronounced antiretroviral activity in mice infected with Moloney murine sarcoma virus (MSV), but, as to the clinical potential of the DAPys no further information has been forthcoming lately. 
As could be easily predicted from their chemical structure (Fig. 7), the DAPys behave as purine mimetics [52]; at least they do so in the reverse transcriptase reaction. The "open", incomplete purine ring of the DAPys would allow the canonical Watson-Crick base pairing of PMEO-DAPy with thymine. This canonical Watson-Crick base pairing requires hydrogen bonding between the $\mathrm{C}_{4}-\mathrm{NH}_{2}$ of DAPy and the $\mathrm{C}_{4}-\mathrm{O}$ of thymine, and between the $\mathrm{N}_{3}-\mathrm{H}$ of thymine and the $\mathrm{N}_{3}$ of DAPy, but according to the Watson-Crick base pairing rules, there is a third hydrogen bonding possible, that is between the $\mathrm{C}_{2}-\mathrm{O}$ of thymine and the $\mathrm{C}_{2}$ $\mathrm{NH}_{2}$ of DAPy (equivalent to the hydrogen bonding between the $\mathrm{C}_{2}-\mathrm{O}$ of cytosine and the $\mathrm{C}_{2}$ $\mathrm{NH}_{2}$ of guanine in the canonical Watson-Crick base pairing between cytosine and guanine). This may in the case of the DAPys explain why they are incorporated more efficiently than $(R)$-PMPA and not excised as efficiently as (R)-PMPA. Whether this "third" hydrogen bond translates into a better therapeutic and/or resistance profile of PMEO-DAPy and $(R)$-PMPADAPy, as compared to PMEA and (R)-PMPA, respectively, is an intriguing possibility, worthy of further exploration.

Much about the therapeutic (or prophylactic) usefulness of the DAPy derivatives still has to be revealed. The superiority of $(R)$-HPMPO-DAPy, like that of $(S)$-HPMPC, over vaccination in preventing monkeypox in monkeys is but one example [2]. Also, the impact of esterification of the DAPy derivatives [(R)-HPMPO-DAPy, PMEO-DAPy and (R)-PMPA-DAPy] with alkoxyalkyls such as hexadecyloxypropyl (HDP) or octadecyloxyethyl (ODE) should be further examined.

\section{9. (S)-HPMPC-5-aza (and its alkoxyalkyl prodrugs), or the effect of replacing a pyrimidine} by a triazine moiety 
Replacing the pyrimidine ring in (S)-HPMPC by a triazine ring (Fig. 8) resulted in the formation of (S)-HPMPC-5-aza, which exhibited activity against DNA viruses that was comparable to, or even better than, that of the parent compound [53]. This antiviral activity could be further enhanced by introduction of alkoxyalkyl groups, the most active being the hexadecyloxyethyl (HDE) ester (Fig. 8) [54]. HDE-(S)-HPMPC-5-aza should be further explored for its therapeutic potential in the treatment of those virus infections that are sensitive to cidofovir, in particular CMV, HSV, HPV, adeno- and poxvirus infections.

The (S)-HPMPC-5-aza derivatives may be advantageous over (S)-HPMPC and its derivatives, since the intracellular metabolism of (S)-HPMPC-5-aza is different from that of (S)-HPMPC, in that it has a lower sensitivity to catabolic deamination and higher rate of phosphorylation and DNA incorporation [55]. This may possibly be reflected by a better therapeutic potential, in the clinical setting, in the treatment of certain virus infections. In addition, (S)-HPMPC-5-aza can be readily decomposed to the $\mathrm{N}$-formylguanidine and further onto the carbamoylguanidine derivatives which do not exhibit either antiviral activity or cytotoxicity. This rapid decomposition may limit the nephrotoxic potential [56], which could make it advantageous over cidofovir under conditions where nephrotoxicity may be a limiting factor.

\section{The anticancer potential of acyclic nucleoside phosphonates, a barely explored therapeutic opportunity}

In earlier studies we have pointed to the antitumor activity of both PMEA, its 2,6diaminopurine analogue (PMEDAP) and the $\mathrm{N}^{6}$-cyclopropyl derivative thereof (cPrPMEDAP) $[57,58]$, and (S)-HPMPC [59-61]. These antitumor effects were not further explored, however. Instead, two phosphonoamidate prodrugs of cPrPMEDAP, namely GS-9191 and 
GS-9219, have been further pursued for their anticancer potential: (i), GS-9191 (Fig. 9) (Lphenylalanine, $\mathrm{N}, \mathrm{N}^{\prime}$-[[[2-[2-amino-6-(cyclopropylamino)-9H-purin-9-yl]ethoxy]methyl]phosphinylidene]bis-,bis(2-methylpropyl) ester), as a topical prodrug of PMEG [9-(2phosphonylmethoxyethyl)guanine] for the local treatment of HPV lesions [62] and (ii) GS9219 (Fig. 9) (diethyl N,N'-[(\{2-[2-amino-6-(cyclopropylamino)-9H-purin-9-yl]ethoxy\}methyl)phosphonoyl]di-L-alaninate), as an intravenous prodrug for the treatment of non-Hodgkin's lymphoma (NHL) in dogs [63]. In both cases, the active cytotoxic agent is PMEG (first described by De Clercq et al. [3]) which, like all other ANPs, has to be converted to its diphosphate, PMEGpp, before being able to interact, as chain terminator, in the DNA polymerase reaction. Thus, in both cases [(i) and (ii)], GS-9191 and GS-9219 act as proprodrugs (or double prodrugs) of PMEG before generating PMEG diphosphate as the ultimate metabolite to unleash the cytotoxic activity. In both cases, the phosphonoamidate prodrugs are intended to direct the PMEG prodrug, CPrPMEDAP to the target tumor cells. The ultimate clinical potential of GS-9191 and 9219, in the (local) treatment of HPV lesions and systemic treatment of NHL, respectively, remains subject of further study.

\section{Intracellular conversion of acyclic (and cyclic) nucleoside phosphonates to their}

\section{diphosphate active metabolite}

To exert their antimetabolic (either antiviral or antitumor) activity, all nucleoside phosphonates have to undergo two intracellular phosphorylations, i.e. (S)-HPMPC to (S)HPMPCpp, PMEA to PMEApp, (R)-PMPA to (R)-PMPApp, and PMEG to PMEGpp (Fig. 10), before the latter can compete with the natural substrate, i.e. dCTP, dATP or dGTP, respectively, at the level of the target enzyme(s), the viral DNA polymerase for (S)HPMPCpp, the reverse transcriptase for PMEApp and (R)-PMPApp, and cellular DNA 
polymerases for PMEGpp (Fig. 11). In principle, all the nucleoside phosphonates will act as obligatory chain terminators, although for (S)-HPMPC, two consecutive incorporations may be required before further DNA chain elongation is shut off [25]. Both (S)-HPMPC and (S)HPMPA can be incorporated into the template strand before strongly inhibiting trans-lesion DNA synthesis (in the case of vaccinia virus DNA polymerase) [64]. Emperically, differential activities have been found for the different acyclic nucleoside phosphonates: (i) for $(S)$ HPMPC, (S)-HPMPA and the 2,6-diaminopurine analogue thereof [(S)-HPMPDAP] against a broad spectrum of DNA viruses, (ii) for PMEA, (R)-PMPA and their 2,6-diaminopurine analogues PMEDAP and (R)-PMPDAP against HIV and HBV; and (iii) for CPrPMEDAP, via PMEG, against tumor cells. The molecular mechanism underlying this differential action is not known.

Resistance mutations to any of the acyclic nucleoside phosphonates have been shown to develop, albeit only slowly and partially. The best known are K65R (in the HIV reverse transcriptase for HIV resistance against tenofovir), and the N236T (in the HBV DNA polymerase for HBV resistance against adefovir). Where resistance patterns of poxviruses against ANPs were examined, they were not considered of sufficient concern to undermine the use of ANPs in the treatment of poxvirus infections [65]. Resistance development may, therefore, not seem a major concern of ANPs, whatever virus involved, HIV, HBV, or DNA viruses in general.

\section{Current therapeutic applications of the acyclic nucleoside phosphonates}

The current therapeutic applications of ANPs include (i) for (S)-HPMPC (cidofovir, Vistide ${ }^{\circledast}$ ), CMV retinitis in AIDS patients, and off-label, HSV resistant to acyclovir, HPVassociated lesions [16], polyoma (JC and BK) virus infections [17], adeno- and poxvirus 
infections (i.e. molluscum contagiosum, monkeypox, orf); (ii) for PMEA (adefovir dipivoxil): chronic hepatitis B; and (iii) for (R)-PMPA [tenofovir disoproxil fumarate (TDF, Viread ${ }^{\circledR}$ )], HIV and HBV infections. For the treatment of HIV infections (AIDS), TDF is also available in a fixed-dose drug combination with emtricitabine, as $\operatorname{Truvada}^{\circledR}$, and a fixed-dose drug combination with both emtricitabine and efavirenz, as Atripla ${ }^{\circledR}$.

Forthcoming fixed-dose drug combinations would consist of tenofovir disoproxil fumarate (TDF), emtricitabine and rilpivirine (TMC278), and of tenofovir disoproxil fumarate (TDF), emtricitabine, Elvitegravir (GS-9137) and cobicistat (GS-9350) (the so-called "Quad" pill).

\section{Prophylactic use of tenofovir: prevention of HIV infection}

Several experimental observations, (i) prevention of SIV infection in macaques [35], (ii) prophylaxis of intravaginal exposure of pig-tailed macaques to HIV-2 [66], and (iii) protection of infection of newborn macaques against SIV [67] have pointed to the potential value of tenofovir in the prevention of HIV infection, irrespective of the route of transmission (parenteral, vaginal or perinatal). Complete protection from repeated vaginal SHIV (simian-human immunodeficiency virus) exposures was obtained in macaques with a topical gel containing tenofovir alone or with emtricitabine [68], and both in vitro and ex vivo testing showed tenofovir to be effective as an HIV-1 microbicide [69]. The CAPRISA 004 trial finally showed the effectiveness and safety of vaginal $1 \%$ tenofovir gel as an antiretroviral microbicide, for the prevention of HIV infection in women [70].

In 2006 I wrote [71] that based on (i) the original observations of Tsai et al. [35] that SIV infections in macaques could be completely prevented by tenofovir and (ii) the safety efficacy profile established for tenofovir disoproxil fumarate (TDF) in the treatment of AIDS 
over the past 5-year period (2001-2006) since TDF was approved for clinical use, TDF could be strongly endorsed (as a single daily pill) for the pre- and post-exposure prophylaxis of HIV infections in humans. A number of pre-exposure prophylaxis (PrEP) trials are currently underway with either $\operatorname{Viread}^{\circledR}$ or $\operatorname{Truvada}^{\circledR}$, with as target population: intravenous drug users (Thailand), men and women (Botswana), men having sex with men (Peru, Ecuador, USA, South Africa and Brazil) and discordant couples (Kenya and Uganda) [72]. The results of the PrEP with Truvada ${ }^{\circledR}$ for HIV prevention in men who have sex with men have been recently published [73]: these results indicated a $44 \%$ reduction in the incidence of HIV, following chemoprophylaxis with $\operatorname{Truvada}^{\circledR}$; this protective effect was additional to the comprehensive package of prevention services offered [73].

\section{Conclusion}

Richman et al. recently wrote in Science [74] that the combination therapy for HIV infection represents a triumph for modern medicine, the (only) limitation to the success of this chronic suppressive therapy being the costs involved, the lifelong adherence and the unknown effects of long-term treatment. As an essential component in most of the prevailing combination regimes, tenofovir disoproxil fumarate (TDF) must have contributed to this success.

TDF is but one of the series of either acyclic or cyclic nucleoside phosphonates showing marked antiviral potential. In addition to the "older" acyclic nucleoside phosphonates, (S)-HPMPC, (S)-HPMPA, (S)-HPMPDAP, $(R)$-PMPA and $(R)$-PMPDAP, various "newer" acyclic nucleoside phosphonates such as (R)-HPMPO-DAPy, PMEO-DAPy, 5substituted PMEO-DAPy, (R)-PMEO-DAPy, (S)-HPMPC-5-aza, have been described that yield great potential for the treatment of various DNA virus and retrovirus infections, and so do 
some cyclic nucleoside phosphonates such as the Fd4A phosphonate GS-9148 and its phosphonoamidate prodrug GS-9131. The PMEG prodrug cPrPMEDAP has potential as an anticancer agent, and for all acyclic nucleoside phosphonates may be made orally bioavailable when esterified by an alkyloxyalkyl.

What all the acyclic and cyclic nucleoside phosphonates have in common is that they contain a phosphonate (PCO) linkage, which unlike the phosphate (POC) linkage (Fig. 12), is not readily hydrolyzed. The phosphonate moiety is isosteric to the phosphate present in the natural nucleotides. The various nucleoside phosphonates, particularly the acyclic nucleoside phosphonates (ANPs), show remarkable differences in their antiviral activity spectrum. Why some ANPs, like (S)-HPMPC, $(R)$-HPMPO-DAPy and (S)-HPMPC-5-aza are active against a broad range of DNA viruses, and others, like (R)-PMPA, $(R)$-PMPDAP, $(R)$ PMPO-DAPy, are specifically active against HIV and HBV, largely remains an enigma linked to the "magic" of the phosphonate bound.

\section{Acknowledgements}

I am very much indebted to Mrs. Christiane Callebaut for her faithfully dedicated editorial assistance.

\section{References}

[1] De Clercq E, Holý A, Rosenberg T, Sakuma T, Balzarini J, Maudgal PC. A novel selective broad-spectrum anti-DNA virus agent. Nature 1986; 323:464-467.

[2] Stittelaar KJ, Neyts J, Naesens L, van Amerongen G, van Lavieren RF, Holý A, De Clercq E, Niesters HGM, Fries E, Maas C, Mulder PGH, van der Zeijst BAM, Osterhaus ADME. 
Antiviral treatment is more effective than smallpox vaccination upon lethal monkeypox virus infection. Nature 2006; 439:745-748.

[3] De Clercq E, Sakuma T, Baba M, Pauwels R, Balzarini J, Rosenberg I, Holý A. Antiviral activity of phosphonylmethoxyalkyl derivatives of purine and pyrimidines. Antiviral Res 1987; 8:261-272.

[4] De Clercq E, Holý A. Acyclic nucleoside phosphonates: a key class of antiviral drugs. Nat Rev Drug Discov 2005; 4:928-940.

[5] De Clercq E, Descamps J, De Somer P, Holý A. (S)-9-(2,3-Dihydroxypropyl)adenine : an aliphatic nucleoside analog with broad spectrum antiviral activity. Science 1978; 200:563-565.

[6] Yokota T, Konno K, Chonan E, Mochizuki S, Kojima K, Shigeta S, De Clercq E. Comparative activities of several nucleoside analogs against duck hepatitis B virus in vitro. Antimicrob Agents Chemother 1990; 34:1326-1330.

[7] Yokota T, Mochizuki S, Konno K, Mori S, Shigeta S, De Clercq E. Inhibitory effects of selected antiviral compounds on human hepatitis B virus DNA synthesis. Antimicrob Agents Chemother 1991; 35:394-397.

[8] Beadle JR, Wan WB, Ciesla SL, Keith KA, Hartline C, Kern ER, Hostetler KY. Synthesis and antiviral evaluation of alkoxyalkyl derivatives of 9-(S)-(3-hydroxy-2phosphonomethoxypropyl)adenine against cytomegalovirus and orthopoxviruses. J Med Chem 2006; 49:2010-2015.

[9] Quenelle DC, Collins DJ, Herrod BP, Keith KA, Trahan J, Beadle JR, Hostetler KY, Kern ER. Effect of oral treatment with hexadecyloxypropyl-[(S)-9-(3-hydroxy-2phosphonylmethoxypropyl)adenine] [(S)-HPMPA] or octadecyloxy-ethyl-(S)-HPMPA on 
cowpox or vaccinia virus infections in mice. Antimicrob Agents Chemother 2007; 51:3940-3947.

[10] Hartline CB, Gustin KM, Wan WB, Ciesla SL, Beadle JR, Hostetler KY, Kern ER. Ether lipid-ester prodrugs of acyclic nucleoside phosphonates: activity against adenovirus replication in vitro. J Infect Dis 2005; 191:396-399.

[11] Hostetler KY. Alkoxyalkyl prodrugs of acyclic nucleoside phosphonates enhance oral antiviral activity and reduce toxicity: current state of the art. Antiviral Res 2009; 82:A84-A98.

[12] Balzarini J, Holý A, Jindrich J, Naesens L, Snoeck R, Schols D, De Clercq E. Differential antiherpesvirus and antiretrovirus effects of the (S) and (R) enantiomers of acyclic nucleoside phosphonates: potent and selective in vitro and in vivo antiretrovirus activities of (R)-9-(2-phosphonomethoxypropyl)-2,6-diaminopurine. Antimicrob Agents Chemother 1993; 37:332-338.

[13] Hostetler KY, Aldern KA, Wan WB, Ciesla SL, Beadle JR. Alkoxyalkyl esters of (S)-9-[3hydroxy-2-(phosphonomethoxy)propyl]adenine are potent inhibitors of the replication of wild-type and drug-resistant human immunodeficiency virus type 1 in vitro. Antimicrob Agents Chemother 2006; 50:2857-2859.

[14] Wyles DL, Kaihara KA, Korba BE, Schooley RT, Beadle JR, Hostetler KY. The octadecyloxyethyl ester of (S)-9-[3-hydroxy-2-(phosphonomethoxy) propyl]adenine is a potent and selective inhibitor of hepatitis $C$ virus replication in genotype $1 \mathrm{~A}, 1 \mathrm{~B}$, and 2A replicons. Antimicrob Agents Chemother 2009; 53:2660-2662.

[15] Snoeck R, Sakuma T, De Clercq E, Rosenberg I, Holý A. (S)-1-(3-hydroxy-2phosphonylmethoxypropyl)cytosine, a potent and selective inhibitor of human cytomegalovirus replication. Antimicrob Agents Chemother 1988; 32:1839-1844. 
[16] De Clercq E. Yet another ten stories on antiviral drug discovery (part D): paradigms, paradoxes, and paraductions. Med Res Rev 2010; 30: 667-707.

[17] De Clercq E. The next ten stories on antiviral drug discovery (part E): Advents, Advances, and Adventures. Med Res. Rev 2011; 31:118-160.

[18] Van Cutsem E, Snoeck R, Van Ranst M, Fiten P, Opdenakker G, Geboes K, Janssens J, Rutgeerts P, Vantrappen G, De Clercq E. Successful treatment of a squamous papilloma of the hypopharynx-esophagus by local injections of (S)-1-(3-hydroxy-2phosphonylmethoxypropyl)cytosine. J Med Virol 1995; 45:230-235.

[19] Snoeck R, Wellens W, Desloovere C, Van Ranst M, Naesens L, De Clercq E, Feenstra L. Treatment of severe laryngeal papillomatosis with intralesional injections of cidofovir [(S)-1-(3-hydroxy-2-phosphonylmethoxypropyl)-cytosine]. J Med Virol 1998; 54:219225.

[20] Pransky SM, Magit AE, Kearns DB, Kang DR, Duncan NO. Intralesional cidofovir for recurrent respiratory papillomatosis in children. Arch Otolaryngol Head Neck Surg. 1999;125:1143-1148.

[21] Davis MD, Gostout BS, McGovern RM, Persing DH, Schut RL, Pittelkow MR. Large plantar wart caused by human papillomavirus-66 and resolution by topical cidofovir therapy. J Am Acad Dermatol 2000; 43:340-343.

[22] Meadows KP, Tyring SK, Pavia AT, Rallis TM. Resolution of recalcitrant molluscum contagiosum virus lesions in human immunodeficiency virus-infected patients treated with cidofovir. Arch Dermatol 1997; 133:987-990.

[23] Geerinck K, Lukito G, Snoeck R, De Vos R, De Clercq E, Vanrenterghem Y, Degreef H, Maes B. A case of human orf in an immunocompromised patient treated successfully with cidofovir cream. J Med Virol 2001; 64:543-549. 
[24] De Clercq E. Antiviral drug discovery: Ten more compounds, and ten more stories (part B). Med Res Rev 2009; 29:571-610.

[25] Xiong X, Smith JL, Chen MS. Effect of incorporation of cidofovir into DNA by human cytomegalovirus DNA polymerase on DNA elongation. Antimicrob Agents Chemother 1997; 41:594-599.

[26] Balzarini J, Hao Z, Herdewijn P, Johns DG, De Clercq E. Intracellular metabolism and mechanism of anti-retrovirus action of 9-(2-phosphonylmethoxyethyl)adenine, a potent anti-human immunodeficiency virus compound. Proc Natl Acad Sci USA 1991; 88:1499-1503.

[27] De Clercq E. Antivirals and antiviral strategies. Nat Rev Microbiol 2004; 2:704-720.

[28] Starrett JE Jr, Tortolani DR, Hitchcock MJ, Martin JC, Mansuri MM. Synthesis and in vitro evaluation of a phosphonate prodrug: bis(pivaloyloxymethyl) 9-(2phosphonylmethoxyethyl)adenine. Antiviral Res 1992; 19:267-273.

[29] Cundy KC, Fishback JA, Shaw JP, Lee ML, Soike KF, Visor GC, Lee WA. Oral bioavailability of the antiretroviral agent 9-(2-phosphonylmethoxyethyl)adenine (PMEA) from three formulations of the prodrug bis(pivaloyloxymethyl)-PMEA in fasted male cynomolgus monkeys. Pharm Res 1994; 11:839-843.

[30] Hadziyannis SJ, Tassopoulos NC, Heathcote EJ, Chang TT, Kitis G, Rizzetto M, Marcellin P, Lim SG, Goodman Z, Wulfsohn MS, Xiong S, Fry J, Brosgart CL. Adefovir dipivoxil for the treatment of hepatitis B e antigen-negative chronic hepatitis B. N Engl J Med 2003; 348:800-807.

[31] Marcellin P, Chang TT, Lim SG, Tong MJ, Sievert W, Shiffman ML, Jeffers L, Goodman Z, Wulfsohn MS, Xiong S, Fry J, Brosgart CL. Adefovir dipivoxil for the treatment of hepatitis B e antigen-positive chronic hepatitis B. N Engl J Med 2003; 348:808-816. 
[32] Balzarini J, Holý A, Jindrich J, Dvorakova H, Hao Z, Snoeck R, Herdewijn P, Johns DG, De Clercq E. 9-[(2RS)-3-fluoro-2-phosphonylmethoxypropyl] derivatives of purines: a class of highly selective antiretroviral agents in vitro and in vivo. Proc Natl Acad Sci USA $1991 ; 88: 4961-4965$.

[33] Heijtink RA, Kruining J, de Wilde GA, Balzarini J, De Clercq E, Schalm SW. Inhibitory effects of acyclic nucleoside phosphonates on human hepatitis B virus and duck hepatitis B virus infections in tissue culture. Antimicrob Agents Chemother 1994; $38: 2180-2182$.

[34] De Clercq E. Potential of acyclic nucleoside phosphonates in the treatment of DNA virus and retrovirus infections. Expert Rev Anti-Infect Ther 2003; 1:21-43.

[35] Tsai C-C, Follis KE, Sabo A, Beck,TW, Grant RF, Bischofberger N, Benveniste RE, Black R. Prevention of SIV infection in macaques by (R)-9-(2phosphonylmethoxypropyl)adenine. Science 1995; 270:1197-1198.

[36] Robbins BL, Srinivas RV, Kim C, Bischofberger N, Fridland, A. Anti-human immunodeficiency virus activity and cellular metabolism of a potential prodrug of the acyclic nucleoside phosphonate 9-R-(2-phosphonomethoxypropyl)adenine (PMPA), bis(isopropyloxymethylcarbonyl)-PMPA. Antimicrob Agents Chemother 1998; 42:612617.

[37] Naesens L, Bischofberger N, Augustijns P, Annaert P, Van den Mooter G, Arimilli MN, Kim CU, De Clercq, E. Antiretroviral efficacy and pharmacokinetics of oral bis(isopropyloxycarbonyloxymethyl)-9-(2-phosphonylmethoxypropyl)adenine in mice. Antimicrob Agents Chemother 1998; 42:1568-1573.

[38] Lee WA, He GX, Eisenberg E, Cihlar T, Swaminathan S, Mulato A, Cundy KC. Selective intracellular activation of a novel prodrug of the human immunodeficiency virus 
reverse transcriptase inhibitor tenofovir leads to preferential distribution and accumulation in lymphatic tissue. Antimicrob Agents Chemother 2005; 49:1898-1906.

[39] Painter GR, Almond MR, Trost LC, Lampert BM, Neyts J, De Clercq E, Korba BE, Aldern KA, Beadle JR, Hostetler KY. Evaluation of hexadecyloxypropyl-9-R-[2(Phosphonomethoxy)propyl]- adenine, CMX157, as a potential treatment for human immunodeficiency virus type 1 and hepatitis B virus infections. Antimicrob Agents Chemother 2007; 51:3505-3509.

[40] Lanier ER, Lampert B, Trost L, Painter G, Almond M. Hexadecyloxypropyl tenofovir (CMX157) has enhanced potency in vitro against NRTI-resistant HIV relative to tenofovir and a favourable preclinical profile. Antiviral Ther 2008; 13: Suppl 3, A6, abstract 4 .

[41] Wu T, Froeyen M, Kempeneers V, Pannecouque C, Wang J, Busson R, De Clercq E, Herdewijn P. Deoxythreosyl phosphonate nucleosides as selective anti-HIV agents. J Am Chem Soc 2005; 127:5056-5065.

[42] Kim CU, Luh BY, Martin JC. Regiospecific and highly stereoselective electrophilic addition to furanoid glycals: synthesis of phosphonate nucleotide analogues with potent activity against HIV. J Org Chem 1991; 56:2642-2647.

[43] Cihlar T, Ray AS. Nucleoside and nucleotide HIV reverse transcriptase inhibitors: 25 years after zidovudine. Antiviral Res 2010; 85:39-58.

[44] Cihlar T, Ray AS, Boojamra CG, Zhang L, Hui H, Laflamme G, Vela JE, Grant D, Chen J, Myrick F, White KL, Gao Y, Lin K-Y, Douglas JL, Parkin NT, Carey A, Pakdaman R, Mackman RL. Design and profiling of GS-9148, a novel nucleotide analog active against nucleoside-resistant variants of human immunodeficiency virus type 1 , and its orally 
bioavailable phosphonoamidate prodrug, GS-9131. Antimicrob Agents Chemother $2008 ; 52: 655-665$.

[45] Ray AS, Vela JE, Boojamra CG, Zhang L, Hui H, Callebaut C, Stray K, Lin K-Y, Gao Y, Mackman RL, Cihlar T. Intracellular metabolism of the nucleotide prodrug GS-9131, a potent anti-human immunodeficiency virus agent. Antimicrob Agents Chemother 2008; 52:648-654.

[46] Cihlar T, Laflamme G, Fisher R, Carey AC, Vela JE, Mackman R, Ray AS. Novel nucleotide human immunodeficiency virus reverse transcriptase inhibitor GS-9148 with a low nephrotoxic potential: characterization of renal transport and accumulation. Antimicrob Agents Chemother 2009; 53:150-156.

[47] Holý A, Votruba I, Masojídková M, Andrei G, Snoeck R, Naesens L, De Clercq E, Balzarini J. 6-[2-(Phosphonomethoxy)alkoxy]pyrimidines with antiviral activity. J Med Chem 2002; 45:1918-1929.

[48] Balzarini J, Pannecouque C, De Clercq E, Aquaro S, Perno CF, Egberink H, Holý A. Antiretrovirus activity of a novel class of acyclic pyrimidine nucleoside phosphonates. Antimicrob Agents Chemother 2002; 46:2185-2193.

[49] Hocková D, Holý A, Masojídková M, Andrei G, Snoeck R, De Clercq E, Balzarini J. 5Substituted-2,4-diamino-6-[2-(phosphonomethoxy)ethoxy]pyrimidines-acyclic nucleoside phosphonate analogues with antiviral activity. J Med Chem 2003; 46:50645073.

[50] De Clercq E, Andrei G, Balzarini J, Leyssen P, Naesens L, Neyts J, Pannecouque, C, Snoeck R, Ying C, Hocková D, Holý A. Antiviral potential of a new generation of acyclic nucleoside phosphonates, the 6-[2-(phosphonomethoxy)alkoxy]-2,4diaminopyrimidines. Nucleosides Nucleotides Nucleic Acids 2005; 34:331-341. 
[51] Duraffour S, Snoeck R, Krečmerová M, van Den Oord J, De Vos R, Holý A, Crance J-M, Garin D, De Clercq E, Andrei G. Antimicrob Agents Chemother 2007; 51:4410-4419.

[52] Herman BD, Votruba I, Holý A, Sluis-Cremer N, Balzarini J. The acyclic 2,4diaminopyrimidine nucleoside phosphonate acts as a purine mimetic in HIV-1 reverse transcriptase DNA polymerization. J Biol Chem 2010; 285:12101-12108.

[53] Krečmerová M, Holý A, Pískala A, Masojídková M, Andrei G, Naesens L, Neyts J, Balzarini J, De Clercq E, Snoeck R. Antiviral activity of triazine analogues of 1-(S)-[3hydroxy-2-(phosphonomethoxy)propyl]cytosine (cidofovir) and related compounds. J Med Chem 2007; 50:1069-1077.

[54] Krečmerová M, Holý A, Pohl R, Masojídková M, Andrei G, Naesens L, Neyts J, Balzarini J, De Clercq E, Snoeck R. Ester prodrugs of cyclic 1-(S)-[3-hydroxy-2(phosphonomethoxy)propyl]-5-azacytosine: synthesis and antiviral activity. J Med Chem 2007; 50:5765-5772.

[55] Naesens L, Andrei G, Votruba I, Krečmerová M, Holý A, Neyts J, De Clercq E, Snoeck R. Intracellular metabolism of the new antiviral compound 1-(S)-[3-hydroxy-2(phosphonomethoxy)propyl]-5-azacytosine. Biochem Pharmacol 2008; 76:997-1005.

[56] Dracínský M, Krečmerová M, Holý A. Study of chemical stability of antivirally active 5azacytosine acyclic nucleoside phosphonates using NMR spectroscopy. Bioorg Med Chem 2008; 16:6778-6782.

[57] Hatse S, Naesens L, De Clercq E, Balzarini J. N $\mathrm{N}^{6}$-Cyclopropyl-PMEDAP: a novel derivative of 9-(2-phosphonylmethoxyethyl)-2,6-diaminopurine (PMEDAP) with distinct metabolic, antiproliferative, and differentiation-inducing properties. Biochem Pharmacol 1999; 58:311-323. 
[58] Naesens L, Hatse S, Segers C, Verbeken E, De Clercq E, Waer M, Balzarini J. 9-(2Phosphonylmethoxyethyl)- $\mathrm{N}^{6}$-cyclopropyl-2,6-diaminopurine: a novel prodrug of 9-(2phosphonylmethoxyethyl)guanine with improved antitumor efficacy and selectivity in choriocarcinoma-bearing rats. Oncol Res 1999; 11:195-203.

[59] Liekens S, Andrei G, Vandeputte M, De Clercq E, Neyts J. Potent inhibition of hemangioma formation in rats by the acyclic nucleoside phosphonate analogue cidofovir. Cancer Res 1998; 58:2562-2567.

[60] Liekens S, Verbeken E, De Clercq E, Neyts J. Potent inhibition of hemangiosarcoma development in mice by cidofovir. Int J Cancer 2001; 92:161-167.

[61] Liekens S, Neyts J, De Clercq E, Verbeken E, Ribatti D, Presta M. Inhibition of fibroblast growth factor-2-induced vascular tumor formation by the acyclic nucleoside phosphonate cidofovir. Cancer Res 2001; 61:5057-5064.

[62] Wolfgang GH, Shibata R, Wang J, Ray AS, Wu S, Doerrfler E, Reiser H, Lee WA, Birkus G, Christensen ND, Andrei G, Snoeck R. GS-9191 is a novel topical prodrug of the nucleotide analog 9-(2-phosphonylmethoxyethyl)guanine with antiproliferative activity and possible utility in the treatment of human papillomavirus lesions. Antimicrob Agents Chemother 2009; 53:2777-2784.

[63] Reiser H, Wang J, Chong L, Watkins WJ, Ray AS, Shibata R, Birkus G, Cihlar T, Wu S, Li B, Liu X, Henne IN, Wolfgang GHI, Desai M, Rhodes GR, Fridland A, Lee WA, Plunkett W, Vail D, Thamm DH, Jeraj R, Tumas DB. GS-9219--a novel acyclic nucleotide analogue with potent antineoplastic activity in dogs with spontaneous non-Hodgkin's Iymphoma. Clin Cancer Res 2008; 14:2824-2832.

[64] Magee WC, Aldern KA, Hostetler KY, Evans DH. Cidofovir and (S)-9-[3-hydroxy-(2phosphonomethoxy)propyl]adenine are highly effective inhibitors of vaccinia virus 
DNA polymerase when incorporated into the template strand. Antimicrob Agents Chemother 2008; 52:586-597.

[65] Gammon DB, Snoeck R, Fiten P, Krečmerová M, Holý A, De Clercq E, Opdenakker G, Evans DH, Andrei G. Mechanism of antiviral drug resistance of vaccinia virus: identification of residues in the viral DNA polymerase conferring differential resistance to antipoxvirus drugs. J Virol 2008; 82:12520-12534.

[66] Otten RA, Smith DK, Adams DR, Pullium JK, Jackson E, Kim CN, Jaffe H, Janssen R, Butera S, Folks TM. Efficacy of postexposure prophylaxis after intravaginal exposure of pig-tailed macaques to a human-derived retrovirus (human immunodeficiency virus type 2). J Virol 2000; 74:9771-9775.

[67] Van Rompay KK, McChesney MB, Aguirre NL, Schmidt KA, Bischofberger N, Marthas ML. Two low doses of tenofovir protect newborn macaques against oral simian immunodeficiency virus infection. J Infect Dis 2001; 184:429-438.

[68] Parikh UM, Dobard C, Sharma S, Cong ME, Jia H, Martin A, Pau CP, Hanson DL, Guenthner P, Smith J, Kersh E, Garcia-Lerma JG, Novembre FJ, Otten R, Folks T, Heneine W. Complete protection from repeated vaginal simian-human immunodeficiency virus exposures in macaques by a topical gel containing tenofovir alone or with emtricitabine. J Virol 2009; 83:10358-10365.

[69] Rohan LC, Moncla BJ, Kunjara Na Ayudhya RP, Cost M, Huang Y, Gai F, Billitto N, Lynam JD, Pryke K, Graebing P, Hopkins N, Rooney JF, Friend D, Dezzutti CS. In vitro and ex vivo testing of tenofovir shows it is effective as an HIV-1 microbicide. PLoS One 2010; 5:e9310.

[70] Abdool Karim Q, Abdool Karim SS, Frohlich JA, Grobler AC, Baxter C, Mansoor LE, Kharsany AB, Sibeko S, Mlisana KP, Omar Z, Gengiah TN, Maarschalk S, Arulappan N, 
Mlotshwa M, Morris L, Taylor D; CAPRISA 004 Trial Group. Effectiveness and safety of tenofovir gel, an antiretroviral microbicide, for the prevention of HIV infection in women. Science 2010; 329:1164-1174.

[71] De Clercq E. The role of tenofovir in the prevention of HIV infections. AIDS 2006; 20:1990-1991.

[72] Karim SSA, Baxter C. Antiretroviral prophylaxis for the prevention of HIV infection: future implementation challenges. HIV Ther 2009; 3:3-6.

[73] Grant RM, Lama JR, Anderson PL, McMahan V, Liu AY, Vargas L, Goicochea P, Casapía M, Guanira-Carranza JV, Ramirez-Cardich ME, Montoya-Herrera O, Fernández T, Veloso VG, Buchbinder SP, Chariyalertsak S, Schechter M, Bekker L-G, Mayer KH, Kallás EG, Amico KR, Mulligan K, Bushman LR, Hance RJ, Ganoza C, Defechereux P, Postle B, Wang F, McConnell JJ, Zheng J-H, Lee J, Rooney JF, Jaffe HS, Martinez Al, Burns DN, Glidden DV. Preexposure chemoprophylaxis for HIV prevention in men who have sex with men. N Engl J Med 2010; 363:2587-2599.

[74] Richman DD, Margolis DM, Delaney M, Greene WC, Hazuda D, Pomerantz RJ. The challenge of finding a cure for HIV infection. Science 2009; 323:1304-1307 


\section{Legends to the Figures}

Fig. 1. Structures of (S)-DHPA, PFA, (S)-HPMPA, ODE-(S)-HPMPA and HDP-(S)-HPMPA.

Fig. 2. Structures of (S)-HPMPC, (S)-cHPMPC, ODE-(S)-HPMPC, ODE-(S)-cHPMPC, HDP-(S)HPMPC and HDP-(S)-CHPMPC.

Fig. 3. Structures of PMEA (adefovir) and adefovir dipivoxil.

Fig. 4. Structures of (R)-FPMPA, $(R)$-FPMPDAP, $(R)$-PMPA and (R)-PMPDAP.

Fig. 5. Structures of (R)-PMPA (tenofovir), tenofovir disoproxil fumarate (TDF) and GS-7340.

Fig. 6. Structures of PMDTT, PMDTA, GS-9148 and GS-9131.

Fig. 7. Structures of (R)-HPMPO-DAPy, PMEO-DAPy and (R)-PMPO-DAPy.

Fig. 8. Structures of (S)-HPMP-5-azaC and HDE-(S)-HPMP-5-azaC.

Fig. 9. Structures of GS-9191, GS-9219, cPrPMEDAP and PMEG.

Fig. 10. Structures of (S)-HPMPCpp, PMEApp, (R)-PMPApp and PMEGpp. 
Fig. 11. Modes of action of (S)-HPMPCpp, PMEApp, (R)-PMPApp and PMEGpp.

Fig. 12. Phosphonate bond and phosphate bond. 

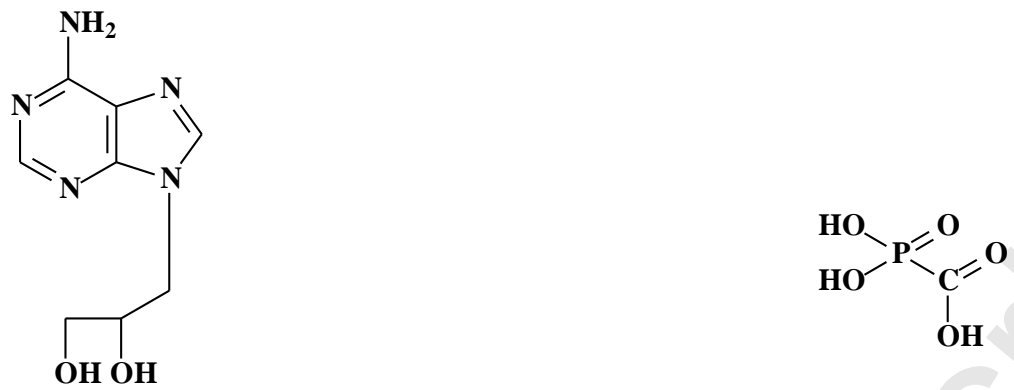

(S)-DHPA

PFA
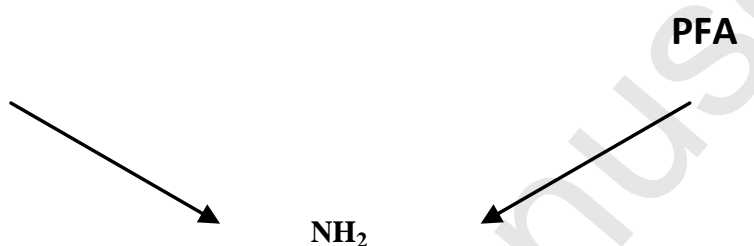<smiles>Nc1ncnc2c1ncn2CC(CO)OCP(=O)(O)O</smiles>

(S)-HPMPA<smiles>CCOCc1ccccc1OP(=O)(O)COC(CO)Cn1cnc2c(N)ncnc21</smiles>

ODE-(S)-HPMPA<smiles>CCCCCOP(=O)(O)COC(CO)Cn1cnc2c(N)ncnc21</smiles>

HDP-(S)-HPMPA

Fig. 1 
<smiles>Nc1ccn(CC(CO)OCP(=O)(O)O)c(=O)n1</smiles>

(S)-HPMPC<smiles>CCCOCOP(=O)(O)COC(CO)Cn1ccc(N)nc1=O</smiles>

ODE-(S)-HPMPC<smiles>CCCCOP(=O)(COC(CO)Cn1ccc(N)nc1=O)OCCCC</smiles>

HDP-(S)-HPMPC<smiles>Nc1ccn(CC2COP(=O)(O)CO2)c(=O)n1</smiles>

(S)-cHPMPC<smiles>CCOCCOP1(=O)COC(Cn2ccc(N)nc2=O)CO1</smiles>

ODE-(S)-CHPMPC<smiles>CCCCOCCOP1(=O)COC(Cn2ccc(N)nc2=O)CO1</smiles>

Fig. 2 
1

2

3

4

5

6

7

8

10

11

12

13

14

15

16

17

18

19

20

21

22

23

24

25

26

27

28

29

30

31

32

33

34

35

36

37

38

39

40

41

42

43

44

45

46

47

48

49

50

51

52

53

54

55

56

57

58

59

60

61

62

63

64

65<smiles>Nc1ncnc2c1ncn2CCOCP(=O)(O)O</smiles>

PMEA

Adefovir<smiles>CC(C)(C)OCOP(=O)(COCCn1cnc2c(N)ncnc21)OCOC(=O)C(C)(C)C</smiles>

Adefovir dipivoxil

Fig. 3

Page 33 of 43 
<smiles>Nc1ncnc2c1ncn2C[C@H](CF)OCP(=O)(O)O</smiles>

(R)-FPMPA<smiles>C[C@@H](Cn1cnc2c(N)ncnc21)OCP(=O)(O)O</smiles>

(R)-PMPA<smiles></smiles>

(R)-FPMPDAP<smiles>C[C@@H](Cn1cnc2c(N)nc(N)nc21)OCP(=O)(O)O</smiles>

(R)-PMPDAP

Fig. 4 
<smiles>CC(Cn1cnc2c(N)ncnc21)OCP(=O)(O)O</smiles>

Tenofovir

(R)-PMPA<smiles>CC(C)OC(=O)OCOP(=O)(CO[C@@H](C)Cn1cnc2c(N)ncnc21)OCOC(=O)OC(C)C</smiles>

Tenofovir disoproxil fumarate (TDF)<smiles>CC(C)OC(=O)CN[PH](=O)(COC(C)Cn1cnc2c(N)ncnc21)Oc1ccccc1</smiles>

\section{GS-7340}

Fig. 5 
<smiles>Cc1cn(C2CC3OC2C3(O)CP(=O)(O)O)c(=O)[nH]c1=O</smiles>

PMDTT<smiles>Nc1ncnc2c1ncn2C1OC(OCP(=O)(O)O)C=C1F</smiles>

GS-9148

(Fd4A phosphonate)<smiles>Nc1ncnc2c1ncn2C1CC2OC1O2</smiles>

PMDTA<smiles>CCOC(=O)CNP(=O)(COC1C=C(F)C(n2cnc3c(N)ncnc32)O1)Oc1ccccc1</smiles>

GS-9131

(Fd4A phosphonoamidate)

Fig. 6 
<smiles>Nc1cc(OCC(CO)OCP(=O)(O)O)nc(N)n1</smiles>

(R)-HPMPO-DAPy<smiles></smiles>

PMEO-DAPY<smiles>CC(COCP(=O)(O)O)Oc1cc(N)nc(N)n1</smiles>

(R)-PMPO-DAPy

Fig. 7 
<smiles>Nc1ncn(CC(CO)OCP(=O)(O)O)c(=O)n1</smiles>

(S)-HPMP-5-azaC<smiles>CCCCOP(=O)(O)COCCn1cnc(N)nc1=O</smiles>

HDE-(S)-HPMP-5-azaC

Fig. 8

28

29

30

31

32

33

34

35

36

37

38

39

40

41

42

43

44

45

46

47

48

49

50

51

52

53

54

55

56

57

58

59

60

61

62

63 
<smiles>CC(C)COC(=O)C(Cc1ccccc1)NP(=O)(COCCn1cnc2c(NC3CC3)nc(N)nc21)N[C@@H](Cc1ccccc1)C(=O)OCC(C)C</smiles>

GS-9191

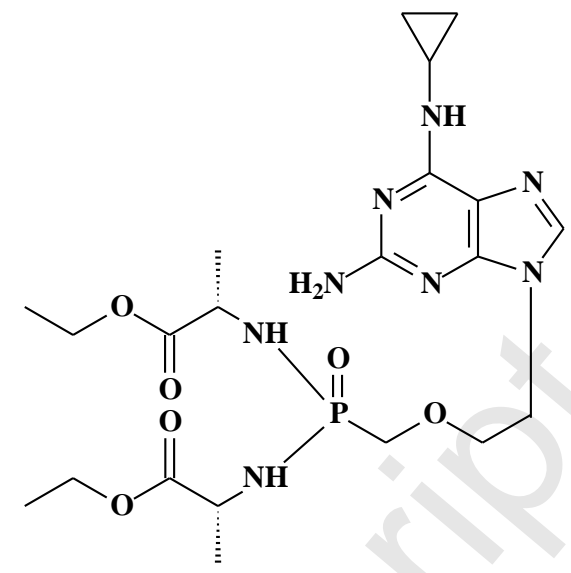

GS-9219<smiles></smiles>

\section{cPrPMEDAP}<smiles>Nc1nc2c(ncn2CCOCP(=O)(O)O)c(=O)[nH]1</smiles>

PMEG

Fig. 9 
<smiles>Nc1ccn(CC(CO)OCP(=O)([O-])OP(=O)([O-])OP(=O)([O-])[O-])c(=O)n1</smiles>

(S)-HPMPCpp<smiles>C[C@H](Cn1cnc2c(N)ncnc21)OCP(=O)([O-])OP(=O)([O-])OP(=O)([O-])[O-]</smiles>

(R)-PMPApp<smiles>Nc1ncnc2c1ncn2CCOCP(=O)([O-])OP(=O)([O-])OP(=O)([O-])[O-]</smiles>

PMEApp<smiles>Nc1nc2c(ncn2CCOCP(=O)([O-])OP(=O)([O-])OP(=O)([O-])[O-])c(=O)[nH]1</smiles>

PMEGpp

Fig. 10 
1

2

3

4

5

6

7

8

10

11

12

13

14

15

16

17

18

19

20

21

22

23

24

25

26

27

28

29

30

31

32

33

34

35

36

37

38

39

40

41

42

43

44

45

46

47

48

49

50

51

52

53

54

55

56

57

58

59

60

61

62

63

64

65

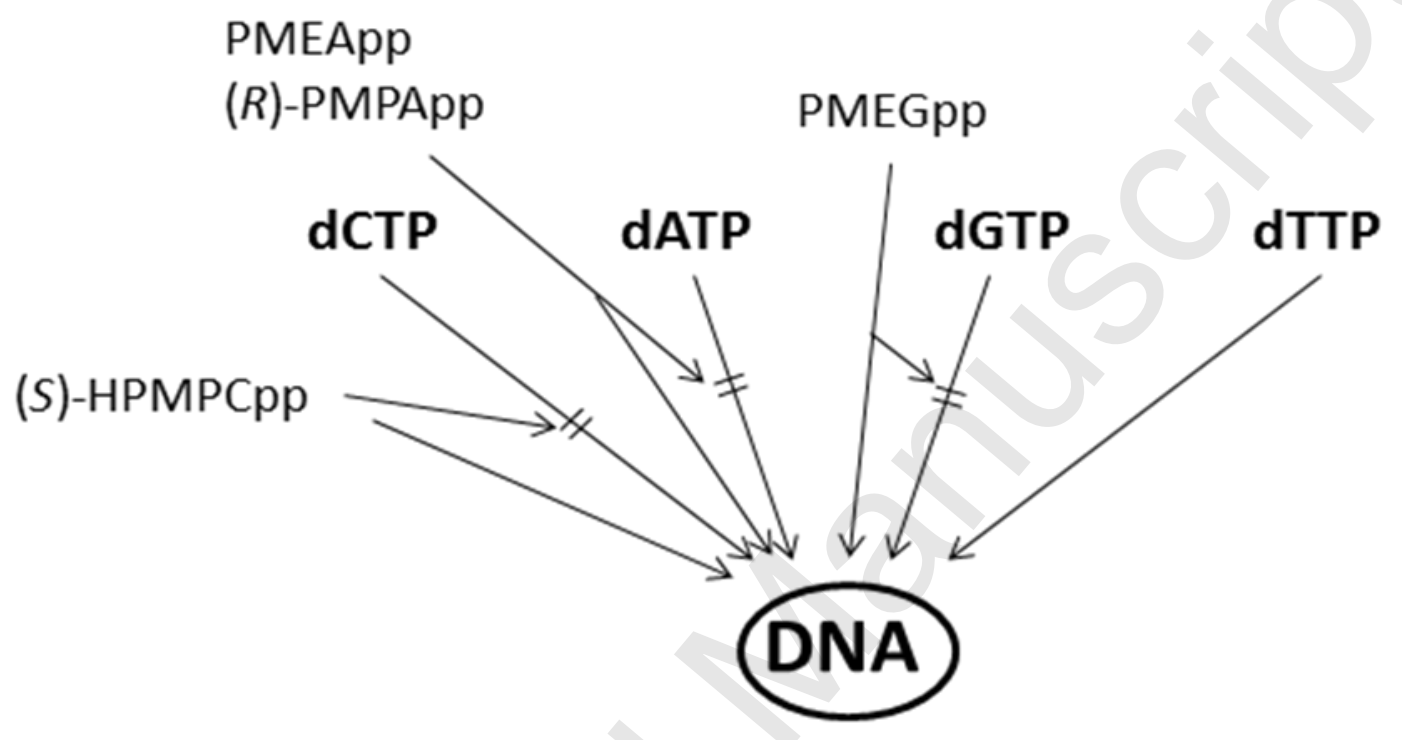

Fig. 11 
1

2

3

4

5

6

7

8

9

10

11

12

13

14

15

16

17

18

19

20

21

22

23

24

25

26

27

28

29

30

31

32

33

34

35

36

37

38

39

40

41

42

43

44

45

46

47

48

49

50

51

52

53

54

55

56

57

58

59

60

61

62

63

64

65<smiles>COCP(=O)(O)O</smiles>

Phosphonate

Fig. 12<smiles>CCOP(=O)(O)O</smiles>

Phosphate 


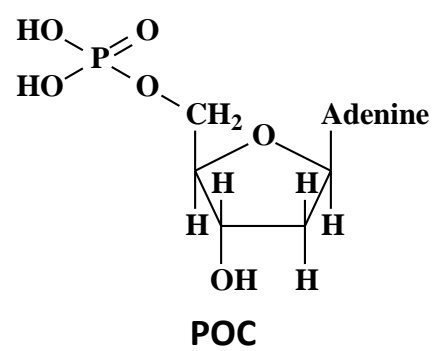

(as in dAMP)

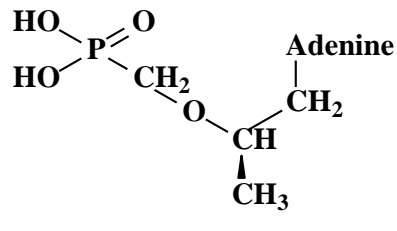

PCO

(as in (R)-PMPA) 